\title{
Responsiveness As Antecedent Of Satisfaction And Referrals In Financial Services Marketing: Empirical Evidence From An Emergent Economy
}

S. K. Pandey, IIM Rohtak, India

Raj Devasagayam, Siena College, USA

\begin{abstract}
Financial institutions across the globe are still recovering from the meltdown of 2008 and several nations continue their struggle to stabilize national economies. However, there might be some important lessons to be learned from this debacle. Some economies, notably the emergent ones, were more resilient to this slowdown than the developed ones. In fact, the banking sector in some of these economies posted a robust growth in spite of the downturn in global banking. We report on a detailed study of a multinational bank operating in the emergent economy of India with a random national sample of over 9,000 of their customers. Our research provides valuable insights into a market driven bank's drive for customer satisfaction and referrals and examines antecedents and consequences of such initiatives. We provide empirical evidence suggesting that responsiveness to customer enquiries and complaints might be a strong driver of customer satisfaction, irrespective of the outcome of the resolution process. Our finding that responsiveness supersedes a positive outcome in service provider-customer conflict resolution is a contribution of this research to extant literature with important strategic and managerial implications for firms.
\end{abstract}

Keywords: Customer Satisfaction; Firm Responsiveness; Dispute Resolution; Financial Services Marketing; Primary Data; National Sample

\section{INTRODUCTION}

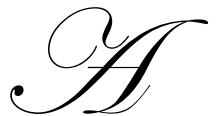

s these words are being penned, the European Union is in the process of resuscitating the economy of Greece from aftershocks of the global meltdown. However, the economic headlines from India seem to be in complete contrast with the banking industry in other parts of the world. For instance, a Wall Street Journal report from 2009 indicated that India (along with Turkey and Argentina) had the bestperforming financial benchmark indexes in their respective regions. The report alluded to a strong and vibrant democracy driving the Indian financial sector in addition to the profitability of banks. This comes as a surprise to most of us in the USA where banks pleaded for aid from the Federal government to maintain liquidity. Contrast this also with not just a transitory event, but a trend in India. Lending by foreign banks in India increased by $16.9 \%$ in 2008 , while lending by private-sector banks rose by $11.8 \%$ in 2008 . Although these lending numbers are about half of the previous year, most analysts are astonished by this performance (WSJ March 30, 2009). The State Bank of India (SBI), which is India's largest nationalized bank by assets and is $60 \%$ owned by the government, has remained focused on its mission to serve rural India and its consumers - small, but many. An estimated 800 million Indians comprise the rural marketplace. This commitment to customer satisfaction has yielded great results, deposit base at SBI rose by close to $40 \%$ in the three months ended Dec. 31, 2008, a the very zenith of financial crisis across the globe! Contrary to other banks, SBI went on a lending spree (a rise of $29 \%$ over the same time period previous year), lowering interest rates, gaining customers from competitors and leading the nation in keeping India's financial sector from joining the global slowdown. The 200-year old bank is busy building its brand identity by repainting its branches with a uniform color scheme, and has invested in customer comfort by adding air conditioning and 
televisions. Further, SBI is reiterating its commitment to customer service by implementing an electronic token system to serve customers more effectively and efficiently. Service quality improvements include a simple smile to be offered along with financial services, a customer-friendly orientation of the service providers.

\section{Research Aim}

The contrast in the banking sectors in two economies; namely, US and India, begs further intellectual enquiry. As a result of the slowdown, the confidence of customers in their banks or banking industry, as a whole, should face the same challenges across the globe. However, India's growth story in the banking sector continues signaling a strong customer satisfaction and trust in the banking system. Our research aim was to learn from the underlying factors driving satisfaction of Indian customers with their banking system. Since satisfaction in financial services marketing is known to be based on the processes adapted to deliver superior service and complaint resolution, an additional aim was to examine the service delivery process and the resultant consumer behavior.

\section{Assumptions}

Several reasonable assumptions were made based on past practice experience and research findings. Customer perception and intentions were measured instead of their behavior and it was assumed that the behaviour was the result of consumer perception and intentions. The relationship between the satisfaction of customers and health of the financial institution was also assumed. The effect of mercenaries (customers who are satisfied but not loyal) was assumed to be negligible. It is important to note that the customers of the bank may be satisfied with the bank but may decide to switch if the competition is perceived as offering a superior value proposition.

\section{Focus Of The Paper}

The focus of this research was to glean generalizable lessons based on the satisfaction of banking customers in India. It was intended to benchmark the process of handling consumer queries with the central bank guidelines. Banking industry was chosen because banks are considered the engines of growth in any economy, especially in an emergent economy such as India. It was assumed that the findings will lead us to some important insights into customer psychology and behavior which would help the strategy formulation by multinational banks and financial institutions.

\section{Research Objectives}

This study attempts to develop a predictive model to examine consumer behavior in the financial services sector based on factors such as customer satisfaction, customer complaints, and complaint resolution time. The specific research issues we examined relate to the relationship between customer satisfaction and product recommendation to a friend, customer satisfaction and case resolution time, optimal time expectations of the customer in complaint and case resolution and its impact on resultant customer satisfaction, and finally the impact of increased customer satisfaction upon propensity to make referrals. A conceptual schematic of the model is presented in Figure 1.

\section{Originality of the paper and contribution to Knowledge}

The paper empirically establishes that responsiveness to customer enquiries and complaints might be a strong driver of customer satisfaction, irrespective of the outcome of the resolution process. Our finding that responsiveness supersedes a positive outcome in service provider-customer conflict resolution is a contribution of this research to extant literature with important strategic and managerial implications for firms.

In the following section, we examine the past research in this stream of enquiry. We then proceed to describe our methodology, review the research results, and follow that section by a discussion of our findings. We conclude with limitations and future research avenues that emerge as a result of this research. 


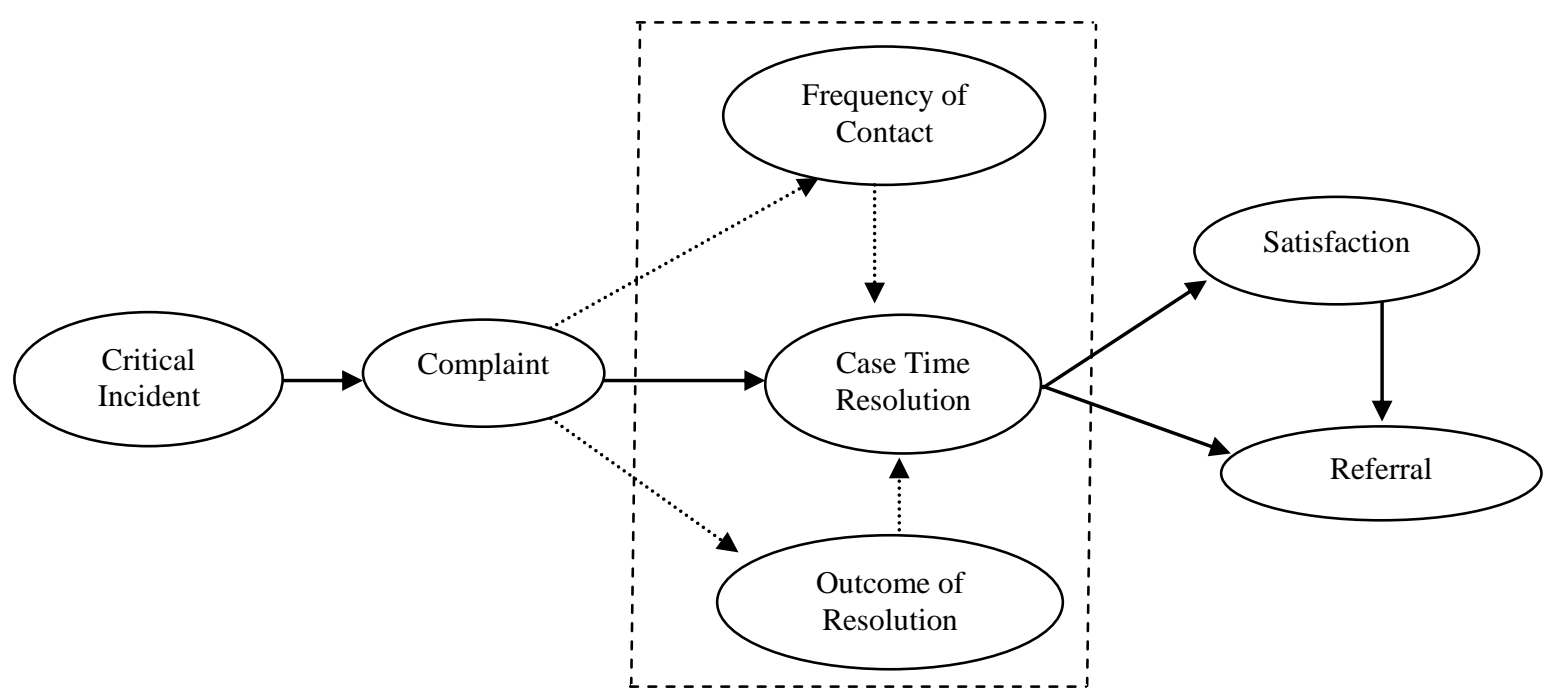

Figure 1: Dispute Resolution

\section{CONCEPTUAL AND THEORETICAL FRAMEWORK}

It seems like the rest of the world may find lessons in the Indian experience with retaining customer confidence, building trust, and assuring customer satisfaction. Our research provides some insights into the Indian banking sector's drive for customer satisfaction and looks at some of the antecedents and consequences of such initiatives. The Datamonitor (2006) report says that many customers are increasingly skeptical of the service that banks provide and are more and more willing to change the provider to get the right kind of service they want. The banking industry is trying out new and innovative initiatives to impress the consumer. Customer satisfaction is no longer the benchmark, but many marketers have coined the term 'customer delight' - delivering quality service beyond customer expectations. The banks are also trying to embrace the concept of customer advocacy where they act in the best interest of the customers, even though it may mean lesser profits in the short run. The importance of customers and their experience is enhanced even more in the services industry because of the intangibility of banking services. Terms like customer relationship management have given way to customer experience management (Rahman 2006, for instance) and companies are trying to maximize the satisfaction derived at each customer touch point. The post-purchase behavior of customers has gained enormous importance in this scenario, especially with unsatisfied customers (Devasagayam and DeMars, 2004, and Hogarth et al, 2001). The banking industry has faced one of the toughest challenges of recession in the recent past. Some of the biggest names were unable to survive this catastrophe and more are in the danger zone. Indian regulators and the Reserve Bank (the central bank in India) were proactive, which prevented any major mayhem in the industry, but the customer confidence was certainly shaken, especially among the private players. The nationalized banks, such as the aforementioned SBI, gained from this loss of confidence in private banks. SBI's financial benchmarks and results bear ample testimony to this effect. In any case, the customer's satisfaction holds the key to long-term sustainability and profitability, but banks realize these hard facts better in troubled times.

This paper uses empirical evidence from one of the largest multinational banks operating in India to underscore some of the conceptual foundations and learning tenets of customer satisfaction and customer complaints resolution mechanism in enhancing overall performance of the banking sector. We contribute to the extant knowledge in not only examining the relationship between complaint resolution, customer satisfaction, and possibility of generating referrals, but also in providing evidence that indicates the importance of firm responsiveness over the outcome of conflict resolution process. In other words, the outcome of the complain resolution being positive or negative is shown to have little bearing on the level of satisfaction when compared to the responsiveness of the firm in resolving the issue. 
An important concept that drives consumer behavior is customer perceived value. Customers are assumed to be rational beings and it is believed that they will pursue and consume superior value propositions. Customer perceived value is the difference between the prospective customer's evaluation of all the benefits and all the costs of an offering and the perceived alternatives (Kotler, 2009). The decision-making process differs based on whether the product is low or high involvement. The banking products purchase usually falls under the high involvement category and customers are expected make rational decisions after considerable thought and evaluation of alternatives.

Bhattacharya and Singh (2008) tried to evaluate various factors considered while making decisions about banks and the resultant satisfaction of customers. As expected, not all variables in the model were desired at equal standards. Some were critical to the decision making and some were perceived as being non-critical. A critical element not present resulted in the customer not purchasing the product, whereas a non-critical element's absence may reduce the perceived value a bit; however, the customer still made a purchase decision in favor of that product. It was proposed that this behaviour had a benefit hierarchy with benefits level, consequence level and end state level. For e.g., in case of banking services, security technology or security procedures are the benefits provided to the consumers. The consequence of these procedures is the reduction in perceived risk of losing money. The end state is that the customer feels safe.

The Bhattacharya and Singh model used the grounded analysis method and qualitatively analyzed the data. The hierarchical model explained perceived value but didn't include behavioral components. That is, it explained what consumers will perceive about the financial service firm and assumed that the customers will behave based on their perception. Our research addresses this gap in the model by testing the findings empirically by simplifying the hierarchical model and adding a behavioral component to the model. In Table 1, we specifically choose the list of Benefit Hierarchies and added Intention to Act as one more dimension.

Table 1: Benefit Hierarchies and Intentions to Act

\begin{tabular}{|c|c|c|c|c|}
\hline S. No. & Benefits Level & Consequence Level & End State Level & Intention to act \\
\hline 1 & $\begin{array}{l}\text { Technical competence/product } \\
\text { knowledge of service personnel }\end{array}$ & $\begin{array}{l}\text { Problem solution regarding } \\
\text { technical issues \& services }\end{array}$ & $\begin{array}{l}\text { Confidence in the } \\
\text { service }\end{array}$ & \\
\hline 2 & $\begin{array}{l}\text { Sales personnel willing to \& capable } \\
\text { of solving problems \& handling } \\
\text { queries }\end{array}$ & $\begin{array}{l}\text { Affinity with the service } \\
\text { provider }\end{array}$ & Solidarity & \\
\hline 3 & People are friendly and courteous & $\begin{array}{l}\text { Likes to interact with } \\
\text { service personnel }\end{array}$ & Feels comfortable & \\
\hline 4 & $\begin{array}{l}\text { Services covers situations which go } \\
\text { beyond stated boundaries }\end{array}$ & Customer Satisfaction & Trust & \\
\hline \multirow{3}{*}{$\begin{array}{l}\text { In our } \\
\text { model }\end{array}$} & Frequency of Contact & Customer Satisfaction & Trust & \multirow{3}{*}{$\begin{array}{l}\text { Recommendation } \\
\text { to a friend }\end{array}$} \\
\hline & Case time resolution & Customer Satisfaction & Trust & \\
\hline & Outcome of resolution & Customer Satisfaction & Trust & \\
\hline
\end{tabular}

\section{LITERATURE REVIEW}

An article in the Banking Wire (2008), which quoted the Forrester Research survey, indicated that among nine industries in the survey, the banking industry finished near the bottom of the heap in customer loyalty. The financial services marketing literature has examined the notion of customer satisfaction with considerable breadth and depth. Aksoy et al (2008) posit that customer satisfaction is a valuable intangible asset that generates positive returns. They showed that investing in a portfolio of firms with high and increasing customer satisfaction is far superior to investing in a portfolio of firms with low and decreasing customer satisfaction. Furthermore, it also beats the S\&P 500 index. The results remained similar, even after adjusting for risk, and these are similar to the findings of previous studies of this nature. Luo and Homburg (2007) found a fascinating result that marketing efforts to enhance customer satisfaction not only make employees feel good about their employer, but may improve employee's future performance. 
Since our study focuses on the emergent economy of India, we specifically focus on some of the past research from this country. Jham and Khan (2008), in an empirical study on Indian banking customer in the region of UP, Delhi and NCR provided evidence that satisfaction results in building better relationships with customers through better services. They concluded that a standardized global strategy affecting performance may not be valid in India, but rather that banks need to develop unique relationship marketing strategies based on the regions they serve. They inferred that since the nature of services is such that interaction of the external customer with the internal customer is essential, satisfaction from these interactions plays a very important role in developing relationships. The results in this research revealed that satisfaction of the customer varies from bank to bank and from customer to customer. This study also provided evidence that customer satisfaction affects banks' sales and profitability.

Beerli et. al. (2002) found the relationship among service quality, customer satisfaction, and image and customer loyalty. They proposed that service quality affects both customer satisfaction and customer loyalty. The customer satisfaction also affects customer loyalty. Along with these, the corporate image of the company also affects customer loyalty. Developing on the theoretical framework of Beerli, Boohene (2011), in the telecommunication industry in Ghana, validated some of the findings. A positive relationship was found between service quality and customer loyalty. Putting up quality mechanisms to increase customer loyalty was validated. Lenka et al (2009) elicited information on human, technical, and tangible aspects of service quality, customer satisfaction, and loyalty. In the Indian banking sector, human aspects were found to be more important than technical and tangible aspects of service quality in influencing customer satisfaction and promoting and enhancing customer loyalty. However, a high level of customer satisfaction may not necessarily result in high customer loyalty. Developing further on the underlying dimensions and relationship between dimensions, Al-alak \& Alnawas (2010) studied the effect of marketing activities on relationship quality in banking sector in Jordan. Using Structural Equation Modeling, it was concluded that greater employee relationship orientation resulted in better relationship quality. Better financial providers for employees resulted in higher relationship quality. Higher relationship quality resulted in better relationship continuity. Committed client relationship resulted in client satisfaction, loyalty, positive word of mouth and promotion. Satisfaction with the service results in positive opinions and actions toward the service provider; however, equally important is to know the consumer behaviour in case of service failure. Customers have low versus high attitudes toward complaining (ATC). Service recovery was found to affect satisfaction more strongly for consumers with high ATC, indicating a moderating role of ATC. This moderator was also supported in the link between satisfaction and complaining intentions. Failure severity and perceived justice influenced satisfaction, which affected repurchase intentions, word of mouth and complaining intentions (De Matos et. al., 2009). There is also a dark side to long-term customer relationships. In the long term, trust loses its influence on the service relationship at the expense of affective commitment. Furthermore, developing exclusive relationships tends to increase the risk of customer reactance, especially when they believe in the organization's representatives' competence and reliability.

Each organization endeavors to provide the best service to its customers. However, mistakes in the critical moment of service delivery and occasional service failures still occur. Customers' evaluations of organizations' responses to their complaints in service encounters are important elements of customer satisfaction and long-term loyalty. Guest focus and commitment is found to be the most influential variable over the organizational responses. On the other hand, the "pre judgments toward guest complaints" variable was found to have a significant negative relationship with organizational responses (Ekiz, 2009). The complaint behavior in organizational settings has also been studied. Henneberg et. al. (2009) found that complaining companies perceive disruptions of their supplier relationships in the context of the business network within which they are embedded, especially vis-à-vis the benefits associated with long-term supplier ties. However, these network concerns are more pronounced for large companies as compared to small firms. The complaining customers have two options; they may remain with the current service provider or switch over. The intentions to switch over are dependent upon their switching costs. Chebat et. al. (2011) found that of the six potential switching cost factors, only two significantly affect the actual behavior of complainants - one directly (continuity costs) and the other as a moderator (learning costs). Likewise, a customer's evaluation of the complaint handling affects behavior directly.

Grigoroudis et al (2008) developed an exploratory model to find the link between economic development and results from national satisfaction barometers such as ACSI (American Customer Satisfaction Index) and SCSB 
(Swedish Customer Satisfaction Barometer). The national satisfaction barometers presented in their paper were able to track trends in customer satisfaction and provide valuable benchmarking insights of the consumer economy for companies, industry trade associations, and government agencies. Lien and Kao (2008) studied the impact of technical and functional quality in shaping customer satisfaction. The results showed that the impact varied in the utilitarian and hedonic services. In utilitarian services, like banks the customers, are more concerned with the service outcome than with the service process; hence, the managers of utilitarian services could consider investing more resources in improving core benefits, especially when competitors are offering similar alternatives.

An article published in Mortgage Banking (2008) quoted a JD Powers' 2008 Home Equity Line/Loan Origination Study finding that there are five key performance indicators for lenders that are critical to satisfying customers: 1) approving applications and providing customers with access to their funds quickly, 2) setting and meeting expectations during the application approval process, 3) avoiding surprising the customer during the origination process, 4) being versatile and flexible in the location of the closing, and 5) being mindful of the pitfalls of using a mortgage broker. The author (Ryan 2008) noted that lenders that perform well in these performance indicators tend to increase their percentage of highly committed customers who are more than twice as likely to recommend their lender to others and to reuse their current lender for their next home-equity or mortgage product. In turn, this growth can help these lenders outperform their competitors over time.

Cooil et al (2007) findings indicate that changes in satisfaction are positively and nonlinearly related to the share of wallet a customer allocates to a particular service provider over time; specifically, the initial satisfaction level and the conditional percentile of change in satisfaction significantly correspond to changes in share of wallet. Second, the findings suggest that the relationship between satisfaction and share of wallet is moderated by both demographic and situational customer characteristics. In particular, income and length of relationship are significant predictors in the model. Both income and length of relationship negatively moderated the relationship between changes in satisfaction and share of wallet.

Mazur (2007) quoted Informa Research Services findings, who sampled 2,863 American consumers nationwide, to find out how they viewed banks and credit unions. The results showed that smaller institutions, such as community banks, received higher ratings for customer satisfaction and loyalty than larger institutions with deposits above $\$ 50$ billion, with notable exceptions being Washington Mutual (WaMu), SunTrust, and Wachovia. Eskildsen and Kristensen (2007) provided evidence of a clear relationship between the perceived transparency and the perceived value. The study also indicated that the relationship differs between industries since the companies from the three different industries form distinct clusters. The analysis of individual industries indicated that the relationship between perceived transparency and perceived value was very strong. A decrease in perceived transparency by 1 index point was shown to be followed by a decrease in perceived value by 0.75 index points and subsequently by a decrease in customer satisfaction.

Clapp (2007) suggests building loyalty is an organizational effort across all customer contact points and business units. Relationship strength is more important than satisfaction as a true indicator of loyalty. Customizing the experience of our customers, in-branch and in-home, impacts the strength of relationship as it builds. Yu (2007) found that customer satisfaction is positively associated with customers' repurchase intentions and the firms' reputation. The impact of overall customer satisfaction is largely attributable to the impact of the responsiveness dimension. He also concluded that while there is no significant and positive relation between customer satisfaction and customer profitability, customer satisfaction does have a positive impact on customer revenue and costs. Interestingly, the findings of this study reveal that higher customer satisfaction leads to higher customer revenue and higher customer costs at the same time, and thus customer profits remain unaffected. Helgesen (2006) study indicated that there seems to be a positive relationship between customer satisfaction and customer loyalty, and there also seems to be a positive relationship between customer loyalty and customer profitability. Both relationships under consideration are found to be nonlinear. Both the relationship between customer satisfaction and customer loyalty and the relationship between customer loyalty and customer profitability seem to be positive at a declining rate.

Morgan and Rego (2006) findings linked average customer satisfaction with gross margins. The found a positive relationship between customer satisfaction and market share. Demonstrating the positive impact of 
customer satisfaction on these important aspects of firm performance considerably enhances support for the key theoretical premise that a firm's ability to satisfy its customers is an important determinant of its business performance. Motley (2005) laid a lot of emphasis on periodic customer satisfaction survey. This study emphasized that apart from satisfaction, the companies should also try to gauge customer loyalty.

Solnik (2007) provided information on how banks today are going beyond traditional methods of collecting and analyzing customer feedback to track customer satisfaction. The newer methods include customer satisfaction kiosks by Citibank and return postage and emails of Suffolk Federal Bank. An article in 2005 in the ABA Bank Marketing highlighted the importance of small things in financial institutions, like making a clean sweep of the bank to remove clutter. According to the article, a series of small changes can instill a connection with customers and make them feel welcome, significant and engaged. Many bank branches who participated in a survey after implementing these small changes found that the customer satisfaction, customer loyalty and employee engagement increased between 10 and $30 \%$.

Mittal et al (2005) found that the association between customer satisfaction and long-term financial performance is positive and relatively stronger for firms that successfully achieve a dual emphasis, successfully achieving both customer satisfaction and efficiency simultaneously. Lee and Hwan (2005) did a study in the Taiwanese banking industry and found that customer satisfaction directly influences purchase intention; furthermore, service quality also influences purchase intention. Loyalty to the bank increases with customer purchase intentions, imperceptibly influencing bank business activity growth and profitability. Viewed from a managerial model perspective, managers consider that customer satisfaction with service quality influences profitability while an actual improvement in service quality also influences profitability. Some perceived service quality discrepancies may exist between the customer and management aspect models.

Motley (2004) argued that smaller banks have been showing higher scores on customer satisfaction because of their focus on the day-to-day, people-to-people service protocols. The larger banks were having a misguided notion that internet banking would replace live bankers. However, the larger banks have also understood the importance of customer satisfaction and are improving their customer satisfaction scores. Sergio (2003) using SEM technique in the financial services industry interestingly found that ethical sales behavior of the frontline sales executives had a direct influence on customer satisfaction with the core service, but not on satisfaction with the company as a whole. Yet, ethical sales behavior and satisfaction with the company were significantly and positively correlated.

Lynn (2000) quoted a Virginia-based consulting firm, TARP, whose 25-year banking industry research showed twice as many people hear about bad experiences than good ones. Customers who are dissatisfied with a bank's attempt to resolve a problem or answer a question will tell as many as 16 friends about it. Customers who complain and have their complaints resolved are more brand-loyal than customers who have no complaints. The study also found out that an increase in loyalty can decrease administrative costs by 10 to 40 percent.

\section{METHODOLOGY}

All these studies make significant contributions in theoretical terms; they fail to provide practical insights that may lead to successful strategy formulations based on the experiences of banks in India. Our research focuses on empirical evidence from an international bank in India that has to compete with a state-owned bank (State Bank of India) that is gaining momentum as a leading competitor. The experience of this bank provides insights in parsimoniously reducing the antecedents of customer satisfaction in the Indian banking sector to a few manageable variables. Theoretically, our model is based on a hierarchical model posited by Bhattacharya and Singh (2009) as described above. One of the limitations of Bhattacharya and Singh's model was the non-inclusion of intentions/actions of customers after satisfaction. It was assumed to result in some actions, such as positive word of mouth, buying intention, etc., but actions may vary. Even an unsatisfied customer may not switch over because of switching costs involved (Chebat et. al., 2011). Hence, there was a need to expand the model and include a dimension of post-satisfaction behaviors, such as repurchase or positive word of mouth. Research indicates that customer satisfaction leads to customer loyalty and the customer then continues to interact with the service provider (Beerli et. al, 2002). 
We build our hypothesis based on these findings. In our research, the attribute level deals with front-line performance on basic service dimensions, the consequence of service is operationalized as case resolution time (irrespective of outcome of such case considerations), and the end-state relates to product recommendation to a friend over a period of time. The case resolution could result in outcomes favorable to the complainant or unfavorable; in both cases, we operationalize the efficiency in terms of time taken to resolve rather than the outcome of the resolution itself. This is in tune with the research findings (de Matos, 2009) that the high ATC customers require a high degree of responsiveness, whereas the low ATC customers base their complaint decision more on satisfaction. The following hypotheses were developed to address the research issues:

H1: There is no significant relationship between case resolution time and customer satisfaction, irrespective of the outcome of the complaint resolution process.

H2: There is no significant relationship between case resolution time and recommendation to a friend, irrespective of the outcome of the complaint resolution process.

H3: There is no significant relationship between customer satisfaction and customer willingness to recommend the bank to a friend.

H4: There is no significant difference between the female and male managers in handling consumer complaints.

\section{Research Method}

The larger research study, that the data are obtained from, was undertaken in the emergent economy of India for a multinational bank with multiple branches numbering in the hundreds and serving both urban and rural populations.

\section{Participants, Procedure and Data Collection}

The cross-sectional data consist of a random sample of customers that had filed a complaint pursuant to service delivery. Data were collected from various branches of the bank over a specific time period. The effective sample size consists of 9,605 who responded to a telephonic survey (participation was voluntary). The survey addressed questions like 1) how many times the customer had to call the bank to solve their complaint and query, 2) based on their experience, would they be willing to recommend the bank to a friend, and 3) their overall rating of the satisfaction, etc.

\section{Measures}

The overall satisfaction, and that of service items, were measured on a five-point scale with 1 being excellent and 5 being poor. The recommendation to the friend was measured on a 10-point likelihood scale with 10 being extremely likely and 1 being extremely unlikely. Case resolution time is the number of days in which the query was resolved and 0 meant that the query was resolved on the day the complaint was raised. The overall satisfaction was measured on a five-point scale with 1 being excellent and 5 being poor. The number of times a person contacted the bank was 1 for one time, 2 for two times, 3 for three times, 4 meant more than or equal to four times, 5 meant that the case was not resolved, and the respondent was provided with the option "cannot recall" to avoid guessing.

\section{STATISTICAL ANALYSIS}

We undertook statistical analyses that range from univariate descriptive statistics to regression. We first established the rationale for our choice of statistical techniques used. Summary statistics were computed to get an idea about the range, mean, standard deviation, and any extreme values in our data set. The descriptive statistics, like mean and standard deviation, are often used for benchmarking the service delivery processes, rendering such values very important in service industry. Enhancing the quality mechanisms has been found to positively affect customer loyalty (Boohene, 2011) and simple modifications in process based on summary benchmarks make customer satisfaction and loyalty a reality in financial services that differentiate themselves via quality in service delivery. 
In the Indian banking sector, human aspects were found to be more important than technical and tangible aspects of service quality in influencing customer satisfaction and promoting and enhancing customer loyalty (Lenka, 2009). Based on this, it was decided to compare the case resolution time variable between the independent groups based on gender of the complaint handler. Since we wanted to test the relationship between metric variables, like case time resolution and recommend to a friend, etc., bivariate correlations were calculated. Regression was used to achieve our overall objective to develop a predictive model of the consumer behaviour based on the variables identified.

Table 2: Descriptive Statistics

\begin{tabular}{|l|c|c|c|c|c|}
\hline & $\mathbf{N}$ & Min & Max & Mean & Std. Dev. \\
\hline Case resolution time (in days) & 9605 & .00 & 198.00 & 12.7041 & 13.48538 \\
\hline & & & & & \\
\hline Recommend to a Friend & 9605 & 1.00 & 10.00 & 7.1498 & 3.17032 \\
\hline & & & & & \\
\hline Times contacted & 9605 & 1.00 & 6.00 & 2.4454 & 1.62647 \\
\hline & & & & & \\
\hline Service Rating & 9605 & 1.00 & 5.00 & 2.5324 & 1.50769 \\
\hline Satisfaction & 9605 & 1.00 & 5.00 & 2.5185 & 1.51612 \\
\hline
\end{tabular}

Table 3: Distribution of Complaint Handlers According to Gender

\begin{tabular}{|l|c|c|c|c|c|}
\hline & Gender & $\mathbf{N}$ & Mean & Std. Deviation & Std. Error Mean \\
\hline \multirow{3}{*}{ CRT } & Male & 2431 & 13.40 & 13.910 & .282 \\
\cline { 2 - 7 } & female & 7086 & 12.48 & 13.331 & .158 \\
\hline
\end{tabular}

Table 4: Independent Samples T Test

\begin{tabular}{|c|c|c|c|c|c|c|c|c|c|c|}
\hline & \multicolumn{2}{|c|}{\begin{tabular}{|c} 
Levene's Test for \\
Equality of Variances
\end{tabular}} & \multicolumn{7}{|c|}{ t-test for Equality of Means } \\
\hline & & \multirow[b]{2}{*}{$\mathbf{F}$} & \multirow[b]{2}{*}{ Sig. } & \multirow[b]{2}{*}{$\mathbf{T}$} & \multirow[b]{2}{*}{ df } & \multirow[b]{2}{*}{$\begin{array}{l}\text { Sig. }(2- \\
\text { tailed) }\end{array}$} & \multirow[b]{2}{*}{\begin{tabular}{|c|} 
Mean \\
Difference
\end{tabular}} & \multirow[b]{2}{*}{$\begin{array}{l}\text { Std. Error } \\
\text { Difference }\end{array}$} & \multicolumn{2}{|c|}{$\begin{array}{l}\text { 95\% Confidence } \\
\text { Interval of the } \\
\text { Difference }\end{array}$} \\
\hline & & & & & & & & & Lower & Upper \\
\hline \multirow[t]{2}{*}{ CRT } & $\begin{array}{l}\text { Equal variances } \\
\text { assumed }\end{array}$ & 3.515 & .061 & 2.902 & 9515 & .004 & .919 & .317 & .298 & 1.541 \\
\hline & $\begin{array}{l}\text { Equal variances not } \\
\text { assumed }\end{array}$ & & & 2.842 & 4064.317 & .005 & .919 & .324 & .285 & 1.554 \\
\hline
\end{tabular}

Table 5: Correlations

\begin{tabular}{|l|l|c|c|c|c|c|}
\hline \multirow{2}{*}{ CRT } & & CRT & Rcomnd friend & Contact & Service rating* & Satisfaction* \\
& Pearson Correlation & 1.000 & $-.067^{* *}$ & $.076^{* *}$ & $-.077^{* *}$ & $-.075^{* *}$ \\
\cline { 2 - 7 } & Sig. (2-tailed) & & .000 & .000 & .000 & .000 \\
\hline \multirow{2}{*}{ Recomnd friend } & Pearson Correlation & $-.067^{* *}$ & 1.000 & $-.493^{* *}$ & $.843^{* *}$ & $.843^{* *}$ \\
\cline { 2 - 7 } & Sig. (2-tailed) & .000 & & .000 & .000 & .000 \\
\hline \multirow{2}{*}{ Service rating } & Pearson Correlation & $.076^{* *}$ & $-.493^{* *}$ & 1.000 & $-.547^{* *}$ & $-.530^{* *}$ \\
\cline { 2 - 8 } & Sig. (2-tailed) & .000 & .000 & & .000 & .000 \\
\hline \multirow{2}{*}{ Satisfaction } & Pearson Correlation & $-.077^{* *}$ & $.843^{* *}$ & $-.547^{* *}$ & 1.000 & $.908^{* *}$ \\
\cline { 2 - 8 } & Sig. (2-tailed) & .000 & .000 & .000 & & .000 \\
\cline { 2 - 8 } & Pearson Correlation & $-.075^{* *}$ & $.843^{* *}$ & $-.530^{* *}$ & $.908^{* *}$ & 1.000 \\
\cline { 2 - 8 } & Sig. (2-tailed) & .000 & .000 & .000 & .000 & \\
\hline
\end{tabular}

*Satisfaction and Service Rating are recoded for consistence of directionality.

**Correlation is significant at the 0.01 level (2-tailed). 
Table 6: Regression between Case Resolution Time and Overall Satisfaction

\begin{tabular}{|c|c|c|c|c|}
\hline Model & R & R Square & Adjusted R Square & Std. Error of the Estimate \\
\hline 1 & $.075(\mathrm{a})$ & .006 & .005 & 1.51196 \\
\hline
\end{tabular}

a Predictors: (Constant), Case Resolution Time

Table 7: ANOVA(b)

\begin{tabular}{|l|l|c|c|c|c|c|}
\hline \multirow{2}{*}{ Model } & & $\begin{array}{c}\text { Sum of } \\
\text { Squares }\end{array}$ & Df & Mean Square & F & Sig. \\
\hline 1 & Regression & 123.212 & 1 & 123.212 & 53.898 & $.000(\mathrm{a})$ \\
\hline & Residual & 21952.758 & 9603 & 2.286 & & \\
\hline
\end{tabular}

a Predictors: (Constant), CRT

b Dependent Variable: overall satisfaction

Table 8: Coefficients(a)

\begin{tabular}{|l|l|c|c|c|c|c|}
\hline \multicolumn{1}{|c|}{ Model } & & \multicolumn{2}{c|}{ Unstandardized Coefficients } & Standardized Coefficients & t & Sig. \\
\hline & & B & Std. Error & Beta & & \\
\hline 1 & (Constant) & 2.412 & .021 & & 113.787 & .000 \\
\hline & CRT & .008 & .001 & .075 & 7.342 & .000 \\
\hline
\end{tabular}

a Dependent Variable: overall satisfaction

Table 9: Regression between Case Resolution Time and Recommend to a Friend

\begin{tabular}{|c|c|c|c|c|}
\hline Model & R & R Square & Adjusted R Square & Std. Error of the Estimate \\
\hline 1 & $.067^{\mathrm{a}}$ & .005 & .004 & 3.16334 \\
\hline
\end{tabular}

a. Predictors: (Constant), Case Resolution Time

Table 10: ANOVA $^{\mathrm{b}}$

\begin{tabular}{|l|l|c|c|c|c|c|}
\hline Model & Sum of Squares & df & Mean Square & F & Sig. \\
\hline \multirow{4}{*}{1} & Regression & 434.897 & 1 & 434.897 & 43.461 & $.000^{\mathrm{a}}$ \\
\cline { 2 - 7 } & Residual & 96094.515 & 9603 & 10.007 & & \\
\cline { 2 - 7 } & Total & 96529.412 & 9604 & & & \\
\hline
\end{tabular}

a. Predictors: (Constant), CRT

b. Dependent Variable: Recommend to a Friend

Table11: Coefficients ${ }^{\mathrm{a}}$

\begin{tabular}{|c|c|c|c|c|c|c|}
\hline & & \multicolumn{2}{|c|}{ Unstandardized Coefficients } & \multirow{2}{*}{$\begin{array}{c}\begin{array}{c}\text { Standardized } \\
\text { Coefficients }\end{array} \\
\text { Beta } \\
\end{array}$} & \multirow[b]{2}{*}{$\mathbf{l}$} & \multirow[b]{2}{*}{ Sig. } \\
\hline \multicolumn{2}{|c|}{ Model } & B & Std. Error & & & \\
\hline \multirow[t]{2}{*}{1} & (Constant) & 7.350 & .044 & & 165.750 & .000 \\
\hline & CRT & -.016 & .002 & -.067 & -6.592 & .000 \\
\hline
\end{tabular}

a. Dependent Variable: Recommend to a Friend

Table 12: Regression between Satisfaction and Recommend to a Friend

\begin{tabular}{|c|c|c|c|c|}
\hline Model & R & R Square & Adjusted R Square & Std. Error of the Estimate \\
\hline 1 & $.843^{\mathrm{a}}$ & .711 & .711 & 1.70480 \\
\hline
\end{tabular}

a. Predictors: (Constant), satisfaction 
Table 13: ANOVA ${ }^{b}$

\begin{tabular}{|l|l|c|c|c|c|c|}
\hline \multicolumn{2}{|l|}{ Model } & Sum of Squares & Df & Mean Square & F & Sig. \\
\hline \multirow{4}{*}{1} & Regression & 68619.928 & 1 & 68619.928 & 23610.510 & $.000^{\mathrm{a}}$ \\
\cline { 2 - 8 } & Residual & 27909.484 & 9603 & 2.906 & & \\
\cline { 2 - 8 } & Total & 96529.412 & 9604 & & & \\
\hline
\end{tabular}

a. Predictors: (Constant), satisfaction

b. Dependent Variable: recomnd friend

Table 14: Coefficients ${ }^{\mathrm{a}}$

\begin{tabular}{|c|c|c|c|c|c|c|}
\hline & & \multicolumn{2}{|c|}{ Unstandardized Coefficients } & \multirow{2}{*}{$\begin{array}{c}\begin{array}{c}\text { Standardized } \\
\text { Coefficients }\end{array} \\
\text { Beta } \\
\end{array}$} & \multirow[b]{2}{*}{$\mathbf{T}$} & \multirow[b]{2}{*}{ Sig. } \\
\hline \multicolumn{2}{|c|}{ Model } & B & Std. Error & & & \\
\hline \multirow[t]{2}{*}{1} & (Constant) & 11.590 & .034 & & 343.627 & .000 \\
\hline & Satisfaction & -1.763 & .011 & -.843 & -153.657 & .000 \\
\hline
\end{tabular}

a. Dependent Variable: recomnd friend

Table 15: Regression between All Variables with Recommend to a Friend

\begin{tabular}{|c|c|c|c|c|}
\hline Model & R & R Square & Adjusted R Square & Std. Error of the Estimate \\
\hline 1 & $.863^{\mathrm{a}}$ & .745 & .745 & 1.59982 \\
\hline
\end{tabular}

a. Predictors: (Constant), servicer, crt, contactt, satisfaction

Table 16: ANOVA ${ }^{b}$

\begin{tabular}{|l|l|c|c|c|c|c|}
\hline \multicolumn{2}{|l|}{ Model } & Sum of Squares & Df & Mean Square & F & Sig. \\
\hline \multirow{4}{*}{1} & Regression & 71958.964 & 4 & 17989.741 & 7028.830 & $.000^{\mathrm{a}}$ \\
\cline { 2 - 8 } & Residual & 24570.448 & 9600 & 2.559 & & \\
\cline { 2 - 8 } & Total & 96529.412 & 9604 & & & \\
\end{tabular}

a. Predictors: (Constant), servicer, CRT, contactt, satisfaction

b. Dependent Variable: recomnd friend

Table 17: Coefficients ${ }^{\mathrm{a}}$

\begin{tabular}{|c|c|c|c|c|c|c|}
\hline & & \multicolumn{2}{|c|}{ Unstandardized Coefficients } & \multirow{2}{*}{$\begin{array}{c}\begin{array}{c}\text { Standardized } \\
\text { Coefficients }\end{array} \\
\text { Beta } \\
\end{array}$} & \multirow[b]{2}{*}{$\mathbf{t}$} & \multirow[b]{2}{*}{ Sig. } \\
\hline \multicolumn{2}{|c|}{ Model } & B & Std. Error & & & \\
\hline \multirow[t]{5}{*}{1} & (Constant) & 11.873 & .036 & & 325.430 & .000 \\
\hline & CRT & .000 & .001 & .001 & .110 & .913 \\
\hline & satisfaction & -.916 & .026 & -.438 & -35.471 & .000 \\
\hline & contactt & -.049 & .012 & -.025 & -4.067 & .000 \\
\hline & servicer & -.908 & .026 & -.432 & -34.509 & .000 \\
\hline
\end{tabular}

a. Dependent Variable: recomnd friend

Table 18: KMO and Bartlett's Test

Kaiser-Meyer-Olkin Measure of Sampling Adequacy.

Bartlett's Test of Sphericity

\begin{tabular}{|l|c|}
\hline Approx. Chi-Square & $\mathbf{. 7 6 2}$ \\
\hline Df & 29828.931 \\
\hline Sig. & 3 \\
\hline
\end{tabular}


Table 19: Communalities

\begin{tabular}{|l|c|c|}
\hline & Initial & Extraction \\
\hline Recomndfriend & 1.000 & .879 \\
\hline Satisfaction & 1.000 & .925 \\
\hline Servicer & 1.000 & .925 \\
\hline
\end{tabular}

Extraction Method: Principal Component Analysis.

Table 20: Total Variance Explained

\begin{tabular}{|l|c|c|c|c|c|c|}
\hline \multirow{2}{*}{ Component } & \multicolumn{3}{|c|}{ Initial Eigenvalues } & \multicolumn{3}{c|}{ Extraction Sums of Squared Loadings } \\
\cline { 2 - 7 } & Total & \% of Variance & Cumulative \% & Total & \% of Variance & Cumulative \% \\
\hline 1 & 2.730 & 90.993 & 90.993 & 2.730 & 90.993 & 90.993 \\
\hline 3 & .178 & 5.941 & 96.933 & & & \\
\hline
\end{tabular}

Table 21: Component Matrix ${ }^{\text {a }}$

\begin{tabular}{|l|c|}
\hline \multirow{2}{*}{ recomndfriend } & Component \\
\cline { 2 - 2 } Satisfaction & 1 \\
\hline Servicer & -.938 \\
\hline
\end{tabular}

Extraction Method: Principal Component Analysis.

a. 1 components extracted.

Table 22: Model Summary

\begin{tabular}{|c|c|c|c|c|}
\hline Model & R & R Square & Adjusted R Square & Std. Error of the Estimate \\
\hline 1 & $.550^{\mathrm{a}}$ & .302 & .302 & .83534303 \\
\hline
\end{tabular}

a. Predictors: (Constant), contactt, ctr

Table 23: ANOVA ${ }^{b}$

\begin{tabular}{|l|l|c|c|c|c|c|}
\hline Model & Sum of Squares & Df & Mean Square & F & Sig. \\
\hline \multirow{4}{*}{1} & Regression & 2903.744 & 2 & 1451.872 & 2080.648 & $.000^{\text {a }}$ \\
\cline { 2 - 8 } & Residual & 6700.256 & 9602 & .698 & & \\
\cline { 2 - 7 } & Total & 9604.000 & 9604 & & & \\
\hline
\end{tabular}

a. Predictors: (Constant), contactt, ctr

b. Dependent Variable: consequence

Table 24: Coefficients ${ }^{\mathrm{a}}$

\begin{tabular}{|c|c|c|c|c|c|c|}
\hline & & \multicolumn{2}{|c|}{ Unstandardized Coefficients } & \multirow{2}{*}{$\begin{array}{c}\begin{array}{c}\text { Standardized } \\
\text { Coefficients }\end{array} \\
\text { Beta } \\
\end{array}$} & \multirow[b]{2}{*}{$t$} & \multirow[b]{2}{*}{ Sig. } \\
\hline \multicolumn{2}{|c|}{ Model } & B & Std. Error & & & \\
\hline \multirow[t]{3}{*}{1} & (Constant) & -.854 & .017 & & -50.413 & .000 \\
\hline & ctr & .003 & .001 & .035 & 4.105 & .000 \\
\hline & contactt & .336 & .005 & .546 & 63.883 & .000 \\
\hline
\end{tabular}

a. Dependent Variable: consequence 


\section{RESEARCH RESULTS}

The statistical analysis conducted resulted in several important results. Some results, such as correlation between Case Time Resolution and satisfaction, etc., were on expected lines. However, the significant difference between the female and male handlers of customer complaints was not anticipated.

\section{Sample Characteristics}

Due to confidentiality issues, no personal characteristics of the respondents may be reported. Except for the customer's account type, we were not provided demographic information such as gender, age, marital status, and income of the bank customers. However, we have a gender breakup of the complaint handlers (Table 3) albeit with some missing values that were not included in comparing differences of male and female handlers. Of the data available, approximately $75 \%$ ( $74.5 \%$ ) of the complaint handlers were female and $25 \%$ (25.5\%) were male.

\section{Descriptive Statistics}

On an average, case resolution time for a complaint is approximately 13 days (Table 2), which is well within the prescribed guidelines (30 days) of the Reserve Bank of India - the governing federal body in the financial services sector. There is an ombudsperson-based redressal of grievances in place if the bank does not reply or the reply is unsatisfactory. Individual banks have their own ombudsperson to resolve issues as needed, trying to reduce customer dissatisfaction. However, the standard deviation of case resolution time in the data is high (13.48) with the upper limit going as high as six months (198 days). Some of the satisfaction data (at least for some in our sample) will be influenced by this statistic as we proceed with further analysis. Data suggest that respondents have been active in good word-of-mouth publicity with a rating of 7 on a 10-point scale. This is an important factor for any marketer because the influence of peers in choice decisions, especially in a high involvement product such as financial services, could make or break a product. Satisfaction and service ratings of the bank are both close to 2.5 (2- very good and 3-good), indicating an average response between good and very good. Also, since the customers are very satisfied with the service of the bank, high recommendation to the friend is understood. Respondents reported that, on an average, they had to contact the bank 2.5 times for complaint resolution, which ideally should be only once for most routine queries and complaints. Data indicate that more than one service encounter is needed to perform satisfactory service.

Hypothesis 4 was rejected at 0.05 level. We can say that female problem handlers took less time in solving the problems as compared to their male counterparts (Table 3). The standard deviation is also less, indicating that the females are more consistent in their performance. However, in the independent sample $\mathrm{T}$ test, the assumption of equal variance cannot be rejected at $95 \%$, but can be rejected at $90 \%$. This was indicated in the descriptive analysis that females seemed to be deviating less than their male counterparts. So, at $95 \%$ confidence, we cannot say that females are more consistent than males. However, the difference in the mean time is significant, indicating that females did solve the problems in significantly less time than males (Table 4). At a 90\% confidence level, we can say that females solved the problem in less time and that they were more consistent in doing so as compared to males.

The correlation (Table 5) is significant between all variables and is along expected lines. Customers whose cases were resolved quickly and had to contact less frequently were more satisfied with the bank and they gave a higher rating. They are also very likely to recommend the bank to a friend.

We then proceeded to fit ordinary least squares regression models to further test our hypothesis. Hypothesis 1 was rejected at the 0.05 level of significance (p: $0.0001 ; \mathrm{F}=53.898)$ and the regression coefficients were found to be significant at the 0.0001 level (Tables 7 and 8). The coefficient of determination was low (6\%; Table 6), but the data fit the model well. Customer satisfaction was seen to rise as the amount of time taken to resolve a customer complaint was lowered. However, since the explanation of overall satisfaction was much less by case resolution time, it indicated that factors other than case resolution time also affected overall satisfaction. 
Hypothesis 2 was rejected at the 0.05 level of significance $(\mathrm{p}: 0.0001 ; \mathrm{F}=43.461)$ and the regression coefficients were found to be significant at the 0.0001 level (Tables 9, 10 and 11). This indicated a significant relationship between case resolution time and recommendation to a friend, irrespective of the outcome of the complaint resolution process. The coefficient of determination was very low (0.005) in this case, also indicating the presence of other variables explaining recommendation to a friend.

Hypotheses 3 was also rejected at the 0.05 level of significance (p: $0.0001 ; \mathrm{F}=23610.510)$ and the regression coefficients were found to be significant at the 0.0001 level (Tables 12, 13 and 14). It showed the existence of a significant relationship between customer satisfaction and customer willingness to recommend the bank to a friend. The coefficient of determination was very high (71.1\%).

Considering the results of all the three hypotheses, it can be said that high customer satisfaction would result in high recommendation to a friend, but the causes of satisfaction were more than the case resolution time. Keeping this in mind, all four variables - service rating; complaint resolution time, contact made, and satisfaction rating - were entered into the regression model. The resultant model indicated an excellent fit with a coefficient of determination of 74.5 percent (Tables 15, 16 and 17). All the variables loaded significantly at the 0.001 level, with the exception of case resolution time (p: 0.913). The overall model fit was excellent with $F=7028.830$ (p:0.0001).

Since all variables were significantly correlated with each other, there was an issue of multicollinearity. In our opinion, contact time and case resolution time could be considered as independent variables. They are also the two exactly measurable and quantifiable variables. The other three variables - satisfaction, service rating and recommendation to a friend - can be considered to be the outcome of the two independent variables earlier identified. A factor analysis was conducted to reduce the dependent variables. As expected, only a single factor was extracted explaining approximately $91 \%$ of the original variance contained in the three variables. The factor was named consequence (Tables 18, 19, 20 and 21). Then a regression was run between consequence as the dependant variable and the independent variables identified earlier (Tables 22, 23 and 24). The model was significant and both independent variables contributed significantly in explaining the consequence. However, the overall explanation of the consequence was low $(30 \%)$.

A comparison between case resolution time and number of times contacted reveals that although both are significant, number of times contacted affects the consequence in a bigger way (standardized coefficient 0.546 ) than the time taken to resolve the case (standardized coefficient 0.035). This and the finding that female managers handled the complaints better than their male counterparts are the two most startling findings of the study. The other findings are in line with past research and expectations of this study.

\section{DISCUSSION}

The research results focused on two critical quality aspects of the complaint handling process in a multinational bank - the time taken to resolve the complaint and the number of times the customer contacted the bank for the issue to get resolved. Since both variables were found to significantly affect the consequence, the banks should focus on improvising these quality processes. However, in line with previous research (Bhattacharya and Singh, 1992; Ryan, 2008; and Ekiz, 2009), the two were not found to be equally important. Number of times contacted was considered to be more serious than the time taken for the case to be resolved. This, along with the fact that outcome was also not affecting the overall satisfaction, indicates that managers should try to reduce the number of times a person has to contact the bank for complaint resolution. The finding that female complaint handlers resulted in better overall satisfaction of customers was indeed surprising. The human aspect was found more important than technical ones in Ryan (2008) and it seems that female complaint handlers were better in this regard.

\section{FURTHER RESEARCH AND LIMITATIONS}

The study relates to customers of only one Indian bank. The overall explanation of recommendation to a friend in our research model was 30\%, indicating that there are other important variables that need to be considered. We have included one aspect of behavior - recommend to a friend - but future researches can include intentions of remaining with the bank, as well as cross buying of products from the bank. 


\section{CONCLUSION}

We found that customer satisfaction results in better recommendations to friends, which helps in bringing more customers to the company. Our findings are in line with those of Jham and Khan (2008) that an increase in satisfaction was seen to improve the relationship of the customer with the bank. Our study is also in line with J D Powers because we also find that resolving the case quickly is very important to the customer; therefore, banks should try to reduce this time by all possible means. Our study also is in sync with Lee and Hwan (2005) where they linked customer satisfaction with purchase intention. We also found that customer satisfaction leads to better recommendations to friends. It is conventional wisdom that more people are told bad experiences than good ones; therefore, this study operationalized and empirically examined the effect of satisfaction on recommendations to friends. Bank managers are recommended to try and reduce the number of times a person has to contact the bank to get the query resolved.

An interesting finding of this study relates to the impact of outcome of the complaint resolution process. Effectively, regardless of the outcome of the process (in favor of the customer or not), as long as the bank was perceived to be quick in resolving the complaint, respondents indicated heightened satisfaction. It's even more astonishing that the number of times a person contacted the bank was more significant than the number of days taken to resolve. This might seem counterintuitive on the face of it; however, given a population of more than a billion individuals being served in India, one can empathize with the customer merely clamoring to be heard! Also, the customer is willing to wait provided you still deliver on your specified date and don't make him run again and again. It seems like the respect shown to a customer by merely being responsive far outweighs the actual outcome of the process. This leads to us suggesting future research in the area of comparing this particular aspect with a more developed economy - one with fewer customers being served by a larger number of banks.

In the next phase of our research, we would like to use a structural model-based analysis to simultaneously examine the various paths indicated in our conceptual model. This research focuses on the manifest variables, mainly because of limited availability of data from the bank. Over time, as more data were made available from the larger research study, it will become easier to test for all paths relating to manifest and latent variables, as well as the moderating and mediating variables.

As with most survey-based research, despite our large sample size, we caution the readers to be pragmatic in drawing conclusions based on a small sample from a very large emergent economy of India. Although multiples of hundreds of branches were involved in the study, only one bank (albeit a leader among the largest multinational banks in India and indeed the world) was involved in the study. Generalization of results to other emergent economies might be an erroneous extension of our results.

These limitations also open up new vistas of enquiry, comparative studies across other banks within India; then comparative studies between India and other emergent economies seem to be the natural offshoot of our research. Further researchers can probe the monetary implications on the firm based on our variables of interest in this study. The cost to benefit analysis of such marketing expenditure will add to the popular stream of research on "Return on Marketing (ROM)". Also, some studies have indicated a nonlinear relationship between satisfaction and share of wallet; therefore, similar nonlinear relationship models can be probed for customers and the customers that result from recommendations made to friends. In summary, our findings are of interest to managers and scholars alike and present a first step in what should be a rich and rewarding stream of research in the global financial services marketing sector.

\section{AUTHOR INFORMATION}

Dr. S. K. Pandey is currently an Assistant Professor of Marketing at Indian Institute of Management, Rohtak, India. His qualifications include a Ph.D., M.B.A., UGC-NET and B.Sc. Dr. Pandey has over a decade of teaching experience earlier at institutions like FORE School of Management, Bharati Vidyapeeth's Institute of Management and Research and Delhi Institute of Advanced Studies. He has 14 national publications, 3 international paper presentations, and 6 national paper presentations to his credit. His research interests include consumer behavior, socially responsible behavior and ethics. E-mail: sk.pandey@iimrohtak.ac.in 
Raj Devasagayam, PhD, is a professor of marketing at Siena College, NY. Raj's teaching interests include: marketing strategy, marketing research, sales and sales management, and international marketing. He has received awards for excellence in teaching from peers and students. Raj has published in the areas of dispute resolution, notfor-profits, channels, brand strategies, sports marketing, marketing pedagogy, and corporate social responsibility. His research has appeared in journals such as Journal of Brand Management, Journal of Financial Services Marketing, Marketing Management Journal, and Sport Marketing Quarterly. Raj serves as the Vice President of Publications of the Marketing Management Association. E-mail: raj@siena.edu. Corresponding author.

\section{REFERENCES}

1. Aksoy, L., Cooil, B., Groening, C., Keiningham, T.L. \& Yalcin, A. (2008). The Long-Term Stock Market Valuation of Customer Satisfaction. Journal of Marketing, 72(4), 105-122.

2. Al-alak, B. and Alnawas, I. (2010). "Evaluating the effect of marketing activities on relationship quality in the banking sector: The case of private commercial banks in Jordan". International Journal of Marketing Studies, Vol.2, No.1, pp.78-91.

3. Bank Marketing (2005). Sometimes a Few Little Things Can Go a Long Way to Boost Customer Satisfaction. 37(9), pp 4.

4. Banking Wire (04/10/2008). Customer Satisfaction: Young Folks Ask Banks: Where's The Love?

5. Beerli, A., Martin, D.J. \& Quintana, A. (2002). A model of customer loyalty in the retail banking market. European Journal of Marketing, 38(1), 253-275.

6. Bellman, E. (2009, March 30). State Bank of India - Has Cash, Will Lend. Wall Street Journal (Eastern Edition), p. C. 1.

7. Bhattacharya, S., \& Singh, D. (2008). The Emergence of Hierarchy in Customer Perceived Value for Services: A Grounded Analysis. Journal of American Academy of Business, Cambridge, 13(1), 65-71.

8. Boohene, R. and Agyapong, G. (2011). "Analysis of the antecedents of customer loyalty of telecommunication industry in Ghana: The case of Vodafone (Ghana)". International Business Research, Vol.4, No.1, pp.229-240.

9. Chebat, J., Davidow, M. and Borges, A. (2011). "More on the role of switching costs in service markets: A research note". Journal of Business Research, Vol.64, No.8, pp.823-829.

10. Clapp, B. (2007). Building Loyalty Goes Beyond Good Customer Satisfaction Scores. Bank Marketing, 39(4), 41.

11. Cooil, B., Keiningham, T.L., Aksoy, L., \& Hsu, M. (2007). A Longitudinal Analysis of Customer Satisfaction and Share of Wallet: Investigating the Moderating Effect of Customer Characteristics. Journal of Marketing, 71(1), 67-83.

12. Datamonitor Report. (October 2006). Non-Traditional Players in the Retail Banking Market.

13. De Matos, C., Rossi, C., Veiga, R. and Vieira, V. (2009). "Consumer reaction to service failure and recovery: the moderating role of attitude toward complaining". Journal of Services Marketing, Vol. 23, No.7, pp.462 - 475 .

14. Devasagayam, R. and DeMars, J. (2004). Consumer perceptions of alternative dispute resolution mechanisms in financial transactions. Journal of Financial Services Marketing, 8(4), 378-387.

15. Ekiz, H. (2009). "Factors influencing organizational responses to guest complaints: Cases of Hong Kong and Northern Cyprus", Journal of Hospitality Marketing and Management, Vol.18, No.6, pp.539-573.

16. Eskildsen, J., \& Kristensen, K. (2007). Customer Satisfaction - The Role of Transparency. Total Quality Management \& Business Excellence, 18(1/2), 39-47.

17. Grigoroudis, E., Nikolopoulou, G. \& Zopounidis, C. (2008). Customer Satisfaction Barometers and Economic Development: An Explorative Ordinal Regression Analysis. Total Quality Management \& Business Excellence, 19(5/6), 441-460.

18. Helgesen, O. (2006). Are Loyal Customers Profitable? Customer Satisfaction, Customer (Action), Loyalty and Customer Profitability at the Individual Level. Journal of Marketing Management, 22(3/4), 245-266.

19. Henneberg, S., Gruber, T., Reppel, A., Ashnai, B. and Naude, P. (2009). "Complaint management expectations: An online laddering analysis of small versus large firms". Industrial Marketing Management, Vol.38, No.6, pp.584-598. 
20. Hogarth, J.M., English, M. and Sharma, M. (2001). Consumer complaints and third parties: Determinants of consumer satisfaction with complaint resolution efforts. Journal of Customer Satisfaction,

Dissatisfaction and Complaining Behavior, 14, 74-87.

21. Jham, V., \& Khan, K.M. (2008). Determinants of Performance in Retail Banking: Perspectives of Customer Satisfaction and Relationship Marketing. Singapore Management Review, 30(2), 35-45.

22. Kotler, P., Keller, K. L., Koshy, A. \& Jha, M. (2009). Marketing Management - A South Asian Perspective. Prentice Hall of India. Pg 117.

23. Lee, M.C., \& Hwan, I.S. (2005). Relationships among Service Quality, Customer Satisfaction and Profitability in the Taiwanese Banking Industry. International Journal of Management, 22(4), 635-648.

24. Lenka, U., Suar, D., and Mohapatra, P. (2009). Service Quality, Customer Satisfaction and Customer Loyalty in Indian Commercial Banks. The Journal of Entrepreneurship, 18(1), 47.

25. Lien, Nai-Hwa. \& Kao, Shu-Luan. (2008). The Effects of Service Quality Dimensions on Customer Satisfaction Across Different Service Types: Alternative Differentiation As a Moderator. Advances in Consumer Research - North American Conference Proceedings, 35, 522-526.

26. Luo, X. \& Homburg, C. (2007). Neglected Outcomes of Customer Satisfaction. Journal of Marketing, 71(2), 133-149.

27. Lynn, V. (2000). Customer satisfaction means greater retention. Bank Marketing, $32(1), 19$.

28. Mazur, M. (2007). Community Banks Win in Customer Satisfaction. Community Banker, $16(1), 61$.

29. Mittal, V., Anderson, E.W., Sayrak, A., \& Tadikamalla, P. (2005). Dual Emphasis and the Long-Term Financial Impact of Customer Satisfaction. Marketing Science, 24(4), 544-555.

30. Morgan, N.A., \& Rego, L.L. (2006). The Value of Different Customer Satisfaction and Loyalty Metrics in Predicting Business Performance. Marketing Science, 25(5), 426-439.

31. Mortgage Banking (2008). Customer Satisfaction with HELOC/loan originations up. 68(10), 10-12.

32. Motley, B. (2005). Beyond Customer Satisfaction. Bank Marketing, 37(6), 46.

33. Motley, L.B. (2004). Large Banks Scoring Better on Customer Satisfaction. Bank Marketing, $36(6), 48$.

34. N'Goala, G. (2010). "Discovering the dark side of service relationships... or why long-lasting and exclusive relationships are self-destructing". Recherché et Applications en Marketing, Vol.25, No.1

35. Sergio, R. (2003). The Impact of Ethical Sales Behavior on Customer Satisfaction, Trust and Loyalty to the Company: An Empirical Study in the Financial Services Industry. Journal of Marketing Management, 19(9/10), 915-939.

36. Solnik, C. (10/5/2007). Banking on Customer Satisfaction. Long Island Business News, 54(47).

37. Walker, A.G., Smither, J.W. \& Waldman, D.A. (2008). A Longitudinal Examination of concomitant changes in team leadership and customer satisfaction. Personnel Psychology, 61(3), 547-577.

38. World Beaters: India, Turkey and Argentina --- Key Elections and Improving Emerging-Market Sentiment Aid Gains; Russia Falls Just Short. (2009, July 1). Wall Street Journal (Eastern Edition), p. C.2.

39. Yu, Sui-Hua. (2007). An Empirical Investigation on the Economic Consequences of Customer Satisfaction: The Role of Volume. Total Quality Management and Business Excellence, 18(5), 555-569.

40. Zillur Rehman. (2006). Customer experience management _ A case study of an Indian bank. Journal of Database Marketing and Customer Strategy Management, 13(3), 203-221. 
NOTES 